medRxiv preprint doi: https://doi.org/10.1101/2021.05.07.21256767; this version posted May 14, 2021. The copyright holder for this preprint (which was not certified by peer review) is the author/funder, who has granted medRxiv a license to display the preprint in perpetuity.

It is made available under a CC-BY-NC-ND 4.0 International license .

\title{
Cost savings from managing hypertension in primary health care clinics in Kuwait
}

2 Ayah Odeh ${ }^{1}$, Syed Mohamed Aljunid ${ }^{1}$, Rihab Al-Wotayan ${ }^{2}$, Mahmoud Annaka ${ }^{2}$ and Mohammad Al

3 Mari $^{1}$,

$4 \quad{ }^{1}$ Department of Health Policy and Management, Faculty of Public Health, Kuwait University, Kuwait

$5 \quad{ }^{2}$ Department of Primary Healthcare, Ministry of Health, Kuwait

6 Abstract

7 Background: Generic medications are one of the most common solutions for bringing down

8 pharmaceutical costs for both patients and health care providers. Efforts to increase uptake of generics

9 include policies to support generic substitution and prescription. The aim of this study is to estimate the total cost of drugs prescribed by physicians in selected primary health care centers for managing hypertension and the potential cost savings from substituting generic drugs for branded ones. Methods and Findings: One thousand patients with hypertension were randomly selected from the Primary Care Information System database from among patients who sought treatment at three primary health care centers from Al-Jahra governorate in Kuwait from January to December 2018. Generic antihypertensive drugs were substituted for branded ones, and cost savings were calculated by referring to the International KD 10,093 and with a mean of KD 10.09 ( $\mathrm{SD}=7.34$ ). Only 71 generic drugs had been prescribed, making the generic prescription rate $4.0 \%$. The total number of antihypertensive drugs prescribed was 1,206 (mean: $1.21 ; \mathrm{SD}=0.46)$, with a cost of $\mathrm{KD} 7,678.5($ mean $=\mathrm{KD} 7.68 ; \mathrm{SD}=4.06)$ and with $\mathrm{ACE}$ inhibitors as the most prescribed class at $32.19 \%$. Eight hundred ninety antihypertensive drugs were substituted for 774 patients at estimated cost savings of $\mathrm{KD} 5,675$; that is, substituting generic drugs reduced antihypertensive drug cost by $74 \%$. Conclusion: Generic drug prescription appears to be low among primary care physicians in health care centers in Kuwait, but these centers could see substantial cost savings from substituting generic antihypertensive drugs for branded ones. Active interventions are 
medRxiv preprint doi: https://doi.org/10.1101/2021.05.07.21256767; this version posted May 14, 2021. The copyright holder for this preprint (which was not certified by peer review) is the author/funder, who has granted medRxiv a license to display the preprint in perpetuity.

It is made available under a CC-BY-NC-ND 4.0 International license .

needed to encourage generic prescription among health practitioners to reduce the overall pharmaceutical expenditures.

\section{Introduction}

Countries around the world continue to grapple with increasing health care expenditures, an essential component of which are drugs $[1,2,3]$ with the rise in health care costs driven mainly by population growth, increasing life expectancies, and new technologies. Spending on health accounts for more than $10 \%$ of gross domestic product of most developed countries, with drugs contributing to no less than a fifth of health expenditures [4]. Pharmaceutical spending is growing at an average of $5.7 \%$ every year, faster than other components of health expenditures [5], and the overwhelming spread of chronic diseases is one of the leading causes of the rising health care costs. Patients with chronic illnesses utilize more services and increase the demand for pharmaceuticals $[6,7,8]$. For these reasons, it is imperative that policy makers act innovatively to control these ever-growing expenses without jeopardizing the quality of care provisioned to patients.

Generic drugs are the most common solution for curbing pharmaceutical expenditures and bringing down costs for both patients and governments. They offer the same therapeutic benefit but at prices up to $80 \%$ less than the costs of originators [9]. Encouraging their uptake through generic prescription and substitution has become an integral part of health care policies $[10,11,12]$. The United States achieved a generic drug prescription rate (GDPR) of $90 \%$ that generated savings of up to $\$ 265.1$ billion [13], and the United Kingdom similarly succeeded in achieving a generic prescription rate of 84\%, with overall savings estimated to be $£ 7.1$ billion since 1976 attributable to generic prescription [14]. Furthermore, in Canada, even though generic drugs represent $73 \%$ of all drugs, they account for less than $20 \%$ of the total costs spent on drugs due to their low price [15]. In Kuwait, studies on generic prescription rates are limited. One of the studies conducted in 2010 reported that the generic prescription rate was $17.7 \%$ [16], a percentage deemed extremely low by WHO standards [17].

Meanwhile, as a lifelong illness, hypertension exerts a significant economic burden, especially in developing countries. In the coming years, high blood pressure might cost nearly $\$ 1$ trillion globally in 
medRxiv preprint doi: https://doi.org/10.1101/2021.05.07.21256767; this version posted May 14, 2021. The copyright holder for this preprint (which was not certified by peer review) is the author/funder, who has granted medRxiv a license to display the preprint in perpetuity.

It is made available under a CC-BY-NC-ND 4.0 International license .

direct health spending annually and \$3.6 trillion in indirect costs [18]. As with other chronic conditions,

54 patients with hypertension rely on health services and drugs for lifelong treatment. In Kuwait, 55 hypertension is one of the most debilitating diseases, ranking as the sixth leading cause of death in the country at $37 \%$ of all deaths [19]. With $27.8 \%$ of Kuwait's population estimated to be suffering from

57 hypertension that requires prolonged treatment [19], reducing the cost of antihypertensive drugs could translate to remarkable savings during patients' lifetime. Hence, in this study, we sought to determine the rate of generic drug prescription among primary health care physicians in Kuwait and to estimate the total cost of drugs prescribed for hypertension management as well as the potential cost savings from substituting generic antihypertensive drugs for branded ones.

\section{Methods}

\section{Study design, sampling determination, and source of data}

We conducted this cross-sectional study in three primary health care clinics (PHCCs) located in We used the previously reported PHCC GDPR for Kuwait of $17.7 \%$ [16] to estimate the sample size and used OPENEPI to calculate that a minimum of 224 patients were required, but we selected a sample of 1,000 patients to compensate for the lower GDPR in the benchmarked study. We also gathered the patients' demographic data, diagnoses, and drugs from the Primary Care Information System, ascertaining what drugs had been chosen for substitution from the list of antihypertensive agents in the 2017 Report of 
medRxiv preprint doi: https://doi.org/10.1101/2021.05.07.21256767; this version posted May 14, 2021. The copyright holder for this preprint (which was not certified by peer review) is the author/funder, who has granted medRxiv a license to display the preprint in perpetuity.

It is made available under a CC-BY-NC-ND 4.0 International license.

\section{Data management procedures}

We obtained public prescription prices from the Drug Price List for January 2020 released by the Kuwaiti Ministry of Health's (MOH) Pharmaceutical \& Herbal Medicines Registration \& Control Administration, excluding drugs and other pharmaceutical preparations listed without prices. To calculate the cost of antihypertensive drugs for our analyses, we standardized the treatment duration to one month. We calculated the defined daily dose based on the usual adult maintenance dose for managing hypertension [20]. Hence, the price for one month was as follows: defined daily dose (DDD) $\times 30$ days $\times$ unit price $=$ price in $\mathrm{KD} / \mathrm{month} / \mathrm{drug}$ [21]. For non-antihypertensive drugs, we assumed the cost of one pack except for Vitamin D3 50,000 IU, the cost of which we calculated based on the dosage of one unit per week for a month. We reviewed all prescriptions to identify drugs that had been prescribed as generic or by brand name to calculate the GDPR, which we calculated by dividing the number of generic drugs prescribed by the total number of drugs prescribed.

For the substitutions of generic antihypertensive drugs, we used prices from the International Drug Price Indicator Guide 2015, released by the Management Sciences for Health, Inc., in collaboration with the WHO [22] using the median buyer price/unit. We used the same method to calculate the costs of the originally prescribed drugs along with factoring in shipping costs, inflation rate, and USD conversion rate: DDD $\times$ median unit price from guide $\times 30$ days $\times 10 \%$ shipping $\times$ inflation rate $\times$ conversion rate $=$ price in $\mathrm{KD} /$ month/generic drug. The guide provides generic prices only for essential medications, and as such, we could not substitute all antihypertensive drugs that the physicians at the three PHCCs that we studied had prescribed for their patients. Ultimately, we imputed three main costs for analysis: the total cost of the prescriptions, the cost of antihypertensive drugs, and the amount of savings generated by generic substitution.

\section{Statistical analysis}

We analyzed the study data using Statistical Package for Social Sciences, version 24, with significance set at 5\%. Categorical variables were summarized using frequencies and proportions, and continuous variables were summarized using means and standard deviation, and medians and interquartile 
medRxiv preprint doi: https://doi.org/10.1101/2021.05.07.21256767; this version posted May 14, 2021. The copyright holder for this preprint (which was not certified by peer review) is the author/funder, who has granted medRxiv a license to display the preprint in perpetuity. It is made available under a CC-BY-NC-ND 4.0 International license.

103 ranges. We also used the Mann-Whitney $U$ test to compare the medians of the total prescription costs

104 before and after generic substitution.

\section{Ethical Approval}

106

The study was approved by the Research and Ethics Committee in the Health Sciences Center,

107 Kuwait University and the Standing Committee for coordination of health and medical research in the 108 Ministry of Health. 


\section{Results}

\section{Patient demographics}

In a random sample of 1,000 patients with hypertension, more than half of patients $(57.4 \%)$ were

112 female, and there were slightly more Kuwaiti (50.2\%) than non-Kuwaiti (49.8\%) patients. The mean age

113 of patients was 57.01 years $(\mathrm{SD}=11.82)$, and the median was 56 years. Most of the patients were in the

114 age group of 45 to 64 (61.2\%), and elderly patients (65 and above) represented only $24.5 \%$ of the sample.

115 The duration of illness was only available for 461 patients and had a mean of $11.11(\mathrm{SD}=5.8)$ years

116 (Table 1).

117 Table 1. Clinical and Sociodemographic Profile of Patients.

Characteristic

Number of patients (\%)

Gender

Female

Male

Age (mean \pm SD)

Below 45 years

45-64 years

65 and above

Nationality

Kuwaiti

Non-Kuwaiti

Duration of illness

Less than 5 years

5-9 years

More than 9 years

Total
$574(57.4 \%)$

$426(42.6 \%)$

$57.01 \pm 11.82$

$143(14.3 \%)$

$612(61.2 \%)$

$245(24.5 \%)$

$502(50.2 \%)$

$498(49.8 \%)$

$79(17.1 \%)$

$106(23.0 \%)$

$276(59.9)$

$461(100 \%)$

Mean $11.11 \pm 5.81$ 
medRxiv preprint doi: https://doi.org/10.1101/2021.05.07.21256767; this version posted May 14, 2021. The copyright holder for this preprint (which was not certified by peer review) is the author/funder, who has granted medRxiv a license to display the preprint in perpetuity.

It is made available under a CC-BY-NC-ND 4.0 International license .

\section{Drug prescriptions}

The total number of drugs prescribed for the 1,000 patients was 1,781, with a mean number of

121 drugs prescribed per prescription of $1.78(\mathrm{SD}=1.25)$ and a median of 1 . Over half $(60.4 \%)$ of the patients

122 had been prescribed one drug per visit. Table 2 presents the data on drugs distributed to patients in this

123 study.

124 Table 2. Distribution of Drugs Prescribed to Patients.

Number of drugs per prescription $\quad$ Number of patients $(\%)$

\begin{tabular}{ll}
\hline 1 & $604(60.4 \%)$ \\
2 & $187(18.7 \%)$ \\
3 & $106(10.6 \%)$ \\
4 & $63(6.3 \%)$ \\
5 & $22(2.2 \%)$ \\
6 and above & $18(1.8 \%)$ \\
Total & $1,000(100 \%)$ \\
\hline
\end{tabular}

Providers at the three PHCCs in this study prescribed a total of 71 generic drugs to 56 patients,

127 making the generic prescription rate $4.0 \%$. The average number of generic drugs was $0.07(\mathrm{SD}=0.32)$,

128 with a median of 0 , whereas the average number of branded drugs was $1.71(\mathrm{SD}=1.14)$, with a median of

1291 (Table 3).

130

Table 3. Distribution of Branded and Generic Drugs.

Type of drug prescribed $\quad$ Number of drugs (\%)

$\begin{array}{ll}\text { Generic } & 71(4.0 \%)\end{array}$

Branded $\quad 1,710(96.0 \%)$

Total $\quad 1,781(100 \%)$ 
medRxiv preprint doi: https://doi.org/10.1101/2021.05.07.21256767; this version posted May 14, 2021. The copyright holder for this preprint (which was not certified by peer review) is the author/funder, who has granted medRxiv a license to display the preprint in perpetuity.

It is made available under a CC-BY-NC-ND 4.0 International license .

133 per patient, with a median of 1 . Most patients $(81.7 \%)$ had been prescribed only one antihypertensive

134 drug (Table 4).

135 Table 4. Distribution of Antihypertensive Drugs among Patients.

Number of antihypertensive drugs

Number of patients $(\%)$

\begin{tabular}{ccc}
\hline 1 & $817(81.7 \%)$ \\
2 & $160(16.0 \%)$ \\
3 & $23(2.3 \%)$ \\
Total & $1,000(100 \%)$
\end{tabular}

136

137

The most prescribed class of antihypertensive drugs was angiotensin-converting enzyme

138 inhibitors (ACEIs), representing 32.2\%, followed by calcium channel blockers (CCBs), beta blockers

139 (BBs), and angiotensin ii receptor blockers (ARBs). Tables 5 and 6 present the generic antihypertensive

140 drugs prescribed by type and the branded antihypertensive drugs prescribed, respectively.

141 Table 5. List of Generic Antihypertensive Drug Types Prescribed.

Antihypertensive drugs prescribed by brand name Number (\%)

\begin{tabular}{ll}
\hline Alpha-blockers \& receptor agonists & $10(0.8 \%)$ \\
ACEIs & $385(32.2 \%)$ \\
ARBs & $126(10.6 \%)$ \\
BBs & $136(11.4 \%)$ \\
CCBs & $182(15.2 \%)$ \\
Centrally acting antiadrenergic & $59(4.9 \%)$ \\
Combination drugs & $254(22.0 \%)$ \\
Diuretics & $44(4.0 \%)$ \\
Total & $1,196(100 \%)$
\end{tabular}


medRxiv preprint doi: https://doi.org/10.1101/2021.05.07.21256767; this version posted May 14, 2021. The copyright holder for this preprint

(which was not certified by peer review) is the author/funder, who has granted medRxiv a license to display the preprint in perpetuity.

It is made available under a CC-BY-NC-ND 4.0 International license .

Table 6. List of Branded Antihypertensive Drugs Prescribed.

\begin{tabular}{lc} 
Antihypertensive drugs prescribed by generic & Number $(\%)$ \\
name & $1(10 \%)$ \\
\hline Amlodipine & $2(20 \%)$ \\
Captopril & $3(30 \%)$ \\
Cilazapril & $1(10 \%)$ \\
Clindipine & $1(10 \%)$ \\
Losartan & $2(20 \%)$ \\
Valsartan & $10(100 \%)$ \\
Total &
\end{tabular}

143

144

Drug costs

145

The overall cost of drugs for all 1,000 patients was KD 10,092.99, with a mean of KD 10.09 (SD

146 $=7.34$ ) and a median of KD 8.06. Most patients' prescriptions (83\%) cost less than KD 15. Tables 7 and

1478 present the data on the overall and hypertensive drug costs and the distributions among the patients.

\section{Cost of antihypertensive drugs}

The total cost of antihypertensive drugs was $\mathrm{KD} 7,678.49$, representing $76 \%$ of the total cost of all prescriptions. The average cost of antihypertensive drugs was KD 7.68, and more than a third (40.2\%)

151 of the antihypertensive drugs cost less than KD 10.

152 Amount of cost savings

The total amount of savings achieved by substituting generic antihypertensive drugs for branded drugs for 774 patients was KD 5,675.04. Substituting 890 antihypertensive drugs (73.8\%) reduced total 155 prescription costs by $56.2 \%$ and total antihypertensive drug costs by $73.9 \%$. 
medRxiv preprint doi: https://doi.org/10.1101/2021.05.07.21256767; this version posted May 14, 2021. The copyright holder for this preprint (which was not certified by peer review) is the author/funder, who has granted medRxiv a license to display the preprint in perpetuity.

It is made available under a CC-BY-NC-ND 4.0 International license .

Table 7. Drug Costs for 1,000 Patients.

\begin{tabular}{lcccccc} 
Cost & Total $(\mathrm{KD})$ & Mean & SD & Median & IQR & Mode \\
\hline Total cost of prescription & $10,092.99$ & 10.09 & 7.34 & 8.06 & 6.38 & 8.06 \\
Cost of antihypertensive drugs & $7,678.49$ & 7.68 & 4.06 & 7.16 & 5.73 & 11.76 \\
Cost of prescription after generic substitution & $4,417.97$ & 4.42 & 6.53 & 2.13 & 3.24 & 0.56 \\
Cost of antihypertensive drugs after generic & $2,003.47$ & 2.00 & 2.26 & 0.91 & 3.24 & 0.56 \\
substitution & & & & & & \\
Amount of cost saving & & & & & & \\
& $5,675.04$ & 5.68 & 4.32 & 5.19 & 7.81 & 0
\end{tabular}

160

Table 8. Drug Cost Distribution among Patients.

Number of patients $(\%)$

\begin{tabular}{llll} 
Cost $(\mathrm{KD})$ & Cost of & Cost of antihypertensive & Amount of savings \\
& prescription & drugs & \\
\hline Less than 5.00 & $247(24.7 \%)$ & $312(31.2 \%)$ & $227(22.7 \%)$ \\
$5.00-9.99$ & $364(36.4 \%)$ & $402(40.2 \%)$ & $232(23.2 \%)$ \\
$10.00-14.99$ & $219(21.9 \%)$ & $244(24.4 \%)$ & $294(29.4 \%)$ \\
15.00 and above & $170(17 \%)$ & $42(4.2 \%)$ & $247(24.7 \%)$ \\
Total & $1,000(100 \%)$ & $1,000(100 \%)$ & $1,000(100 \%)$
\end{tabular}

\section{National cost savings} drugs in Kuwait. Table 9 presents our findings. 
medRxiv preprint doi: https://doi.org/10.1101/2021.05.07.21256767; this version posted May 14, 2021. The copyright holder for this preprint (which was not certified by peer review) is the author/funder, who has granted medRxiv a license to display the preprint in perpetuity.

It is made available under a CC-BY-NC-ND 4.0 International license .

\section{Table 9. National Savings from Generic Substitution of Generic Antihypertensive Drugs.}

Prevalence of hypertension

Population of Kuwait in 2019

Median amount of saving/month/patient

Number of people with hypertension

Amount saved for hypertension population/year
$27.8 \%$

4.7 million

5.187

4.7 million $\times 27.8 \%=1,306,600$

1.3 million $\times 5.187 \times 12=\mathrm{KD} 81,328,010$
169

170

171

172

173

174

To check the robustness of the results, we conducted a sensitivity analysis. We calculated the savings for prevalence rates $10 \%$ lower and $10 \%$ higher than the actual prevalence and for generic substitution rates $26 \%$ above and below the actual substitution rates, representing the best and worst-case scenarios respectively. Table 10 presents the best- and worst-case scenario sensitivity analysis findings.

Table 10. National Savings from Substituting Generic Hypertensive Drugs for Brand Name.

Component

$17.8 \%$ prevalence and $100 \%$ substituted (Best case)

$27.8 \%$ prevalence and $\mathbf{7 4 \%}$ substituted (Base)

$37.8 \%$ prevalence and $48 \%$ substituted (Worst case)
Savings (KD)

$70,274,400$

$\mathbf{8 1 , 3 2 8 , 0 1 0}$

$71,739,108$

Discussion

The main findings of this study are a low GDPR and a promising amount of savings achieved by substituting generic antihypertensive drugs for branded drugs. The majority of the patients were below 64

179 years of age, even though previous researchers have well established that hypertension prevalence in 180 Kuwait [23] and worldwide increases with age, especially after 60 [24]. However, these numbers could merely reflect the governorate's age distribution: in recent statistics, elderly citizens above age 65 represented only $2.1 \%$ of Al-Jahra's inhabitants and 98\% were below 64 years [25]. In 1980, hypertension prevalence among Kuwaiti nationals and non-nationals was $8.3 \%$ in men and $12.9 \%$ in women, and in 
medRxiv preprint doi: https://doi.org/10.1101/2021.05.07.21256767; this version posted May 14, 2021. The copyright holder for this preprint (which was not certified by peer review) is the author/funder, who has granted medRxiv a license to display the preprint in perpetuity.

It is made available under a CC-BY-NC-ND 4.0 International license .

1999, the prevalence among Kuwaitis only was reported to be $28.3 \%$ in men and $22.9 \%$ in women [23].

In this study, the sample had more female than male patients, and in a previous study, on drug compliance among patients with hypertension visiting primary health care clinics, female participants also outnumbered males $(59.8 \%$ to $40.2 \%)$ [26].

The GDPR in this study was $4.0 \%$, lower than the rate of $14.7 \%$ previously reported in Al-Jahra governorate primary health care clinics, and the median number of drugs per prescription was also lower than the previously reported median of 2.6 [16]. These differences, however, could be attributed to the different methodologies in selecting patients. The previous study's authors included prescriptions for general illnesses but excluded chronic diseases such as hypertension, whereas in this study, we studied only patients with hypertension. The objectives of the two studies were different, hence the different inclusion criteria and accompanying differing results.

That being said, both the GDPRs reported in Kuwait in 2010 and in this study are low by WHO standards. Ideally, $100 \%$ of prescriptions are for generic versions [17]. The rates in the neighboring Gulf countries of Kingdom of Saudi Arabia, Bahrain, and United Arab Emirates (2.9\%-19.5\%, 14.3\%, and $7.4 \%$, respectively) are similarly low [16]. In the UK, the GDPR is $84 \%$ [14], and in the United States, it is nearly $90 \%$ [13].

In 2010 , the low generic prescription rate was attributed to the feature of the primary health care electronic system that it only showed drugs by their brand names [16]. This system has since been updated to include both generic international non-propriety and brand names of drugs, and even with that change, prescription by generic names actually decreased. Until recently, the MOH had no official requirement that physicians prescribe generic drugs. Not until January 25, 2020, did a new ministerial decree oblige physicians to prescribe medications by their generic non-propriety names [27]. management, despite their having a key role in selecting treatments. Instead, they base their decisions regarding pharmaceuticals on personal opinion, training, and relationships formed with pharmaceutical companies through drug company representatives and sponsored conventions but without regard to cost. 
medRxiv preprint doi: https://doi.org/10.1101/2021.05.07.21256767; this version posted May 14, 2021. The copyright holder for this preprint (which was not certified by peer review) is the author/funder, who has granted medRxiv a license to display the preprint in perpetuity. It is made available under a CC-BY-NC-ND 4.0 International license .

In turn, drug companies encourage their representatives to build strong relationships with physicians through value-added services to influence their prescription [28]. Moreover, because physicians often encounter brand names of drugs during their training, they are more likely to remember these drugs [16].

213 Therefore, educating physicians on the basics of health care supply management, such as informing them

214 of prices and the potential savings from substituting generics, can help in promoting generic drug 215 prescription in Kuwait.

Moreover, the $\mathrm{MOH}$ should have physicians receive their medication information from academics rather than medical company representatives. Researchers established that in contrast to detailing by medical representatives, academic detailing had a positive influence on physicians' prescription habits that had relied on presenting neutral and evidence-based drug information [29]. The ministry could organize regular interactive sessions led by experts to supply physicians with information on prescription drugs uses.

In addition, although the $\mathrm{MOH}$ has the unofficial policy of allowing pharmacists to switch drug brands according to their availability, the availability of generics in Kuwait is limited, restricting 224 pharmacists' ability to substitute [30]. In this study, nearly all of the antihypertensive drugs prescribed 225 had been branded ones, and the generic drugs prescribed were mainly vitamins, supplements, and 226 antibiotics, but drugs used to treat chronic diseases were prescribed mostly by brand name, perhaps 227 reflecting drug companies' marketing focus on the chronic "diseases of the century" and the drugs to treat 228 them that hold the biggest share of the pharmaceutical market. Furthermore, the five most-prescribed 229 antihypertensive drugs by brand name were all originator-branded drugs that have generic versions on 230 international markets and were among the highest-costing drugs, indicating an opportunity for cost saving 231 by substituting generics.

Kuwait has a high per capita income, which means the demand for quality in health care is high,

233 but the limited indigenous manufacturing capabilities of pharmaceuticals led to dependence on imported 234 pharmaceuticals. In 2017, originator drugs led the pharmaceutical market sales in Kuwait, and generic 235 drug market penetration was limited [31]. In 2019, generics made up only $21.6 \%$ of the Kuwaiti 
medRxiv preprint doi: https://doi.org/10.1101/2021.05.07.21256767; this version posted May 14, 2021. The copyright holder for this preprint (which was not certified by peer review) is the author/funder, who has granted medRxiv a license to display the preprint in perpetuity. It is made available under a CC-BY-NC-ND 4.0 International license .

pharmaceutical market, in contrast to UK and USA where generic prescriptions are as high as $89 \%$ and $81 \%$, respectively [28]. People usually equate high cost with high quality, which has popularized more expensive branded medications over generics and reduced demand for them. Additionally, the high per capita income of most of the Kuwaiti population has led to low patient acceptance of generic drugs [32]. Patients with chronic diseases are accustomed to taking more expensive branded drugs, and they might refuse generic versions for a variety of reasons such as misconceptions regarding their quality. For instance, authors of one study found conflicting opinions on generic and branded medications among patients with diabetes in Kuwait, with some believing that generics were less effective and had more side 244 effects than foreign brands [33]. In another study, in countries where reliance on the public health sector is predominant, patients are more likely to demand the costliest treatments. Patients are aware that generic drugs cost less, but they demand the branded versions because they do not bear the costs [28], which raises the issue of educating patients on the bioequivalence of generics to increase their acceptability. New terms and specifications for the purchase and sale of generic medications in Kuwait were approved back in October 2019, and the MOH has also decided that generic medications will constitute $20 \%$ of all medications in Kuwait and branded ones will represent $80 \%$ [34,35].

During the time period that we studied (January to December 2018), most patients with

252 hypertension had been prescribed one antihypertensive drug, and only $2.3 \%$ had been prescribed three 253 drugs. In the Middle East, $40.5 \%$ of patients received two drugs for hypertension, and only $23.5 \%$ were on monotherapy [36]. In one study in Saudi Arabia, 48.9\% of patients received one antihypertensive drug, $31 \%$ received two, and $23.3 \%$ received three or more [37], and results were similar in a study in Bahrain. Most patients in the latter study (62.9\%) were treated with monotherapy [38]. In Jordan, $46.2 \%$ of patients with hypertension in one study received one drug for managing hypertension, and only $15.6 \%$ received three or more drugs [39]. By contrast, in the United States, most patients with hypertension receive multiple drugs to achieve better control [40].

In this study, angiotensin-converting enzyme inhibitors were the most prescribed class of antihypertensive agents, and of the drugs prescribed, the originator-brand ACEIs and ARBs were among 
medRxiv preprint doi: https://doi.org/10.1101/2021.05.07.21256767; this version posted May 14, 2021. The copyright holder for this preprint (which was not certified by peer review) is the author/funder, who has granted medRxiv a license to display the preprint in perpetuity. It is made available under a CC-BY-NC-ND 4.0 International license .

the costliest. In 1999, the Central Medical Stores had BBs as the top-consumed drugs at $44.7 \%$, followed by ACEIs at $16.9 \%$, centrally acting agents at $13.3 \%, \mathrm{CCBs}$ at $12.5 \%$, diuretics at $12 \%$, vasodilators at $0.3 \%$, and alpha-blockers at $0.2 \%$ [23]. These numbers reflected the whole country's consumption, including primary health care clinics, although ARBs were just newly introduced in Kuwait and as such were not included in the calculations [23]. In previous years, ACEI prescription increased, and indeed, ACEIs were the most prescribed in this study (32.19\%). Among the ACEIs, lisinopril was the most prescribed (37.2\%), which was also the case in 1999 [23]. Lisinopril is also the most widely used ACEI in the United States [40].

In this study, ACEIs accounted for almost half of the total prescription cost, and the major ACEIs prescribed were all originator drugs. Gradual shifts to the use of generic drugs could begin with ACEIs given that they are prescribed the most and cost the most. The second category worth considering for substitution could be CCB. Analysis of the combination drugs revealed that ARBs were prescribed more than CCBs but that CCBs represented $13 \%$ of the antihypertensive drug costs whereas ARBs represented only $10 \%$. ACEIs and CCBs are known to be among the most expensive antihypertensive drugs [41]. For instance, in Bahrain in one study, the cost of ACEIs represented two-thirds of the antihypertensive drug costs even though they were not the most widely used [38].

The US Association for Accessible Medicines reported that the CCB Norvasc (generic name: amlodipine) showed savings of USD 5.7 billion when the generic was substituted, drug savings that ranked among the top 10 [13]. To the best of our knowledge, no previous researchers in Kuwait aimed to impute the amount of savings that could be derived from substituting generic antihypertensive drugs for their branded originals in primary care centers. In the only study we are aware of, Cameron et al. estimated the amount of savings from substituting generics in a number of developing countries, and savings were lowest in Kuwait at $9 \%$ (int $\$ 44,785=\mathrm{KD} 13,778.11$ ) [42]. The savings came from switching six drugs, two of which are antihypertensive drugs included in this study (captopril $25 \mathrm{mg}$ and atenolol $50 \mathrm{mg}$ ), and the low savings were attributed to the low difference between the prices of the branded drugs and their equivalent generics [42]. In that study, generics cost more in Kuwait than in other 
medRxiv preprint doi: https://doi.org/10.1101/2021.05.07.21256767; this version posted May 14, 2021. The copyright holder for this preprint (which was not certified by peer review) is the author/funder, who has granted medRxiv a license to display the preprint in perpetuity.

It is made available under a CC-BY-NC-ND 4.0 International license .

countries, and innovator drugs were purchased from 1.2 to 32.9 times the international reference prices and generics from 0.1 to 22.2 times the international prices [42].

The low number of generics in Kuwait resulted in the absence of the competition that usually drives down drug prices. However, the MOH Pricing Department has been recently adjusting drug prices to account for drugs going off patent and taking into account prices in the region, and as such, it could be worthwhile to repeat this price study in the future to assess if higher savings could be achieved. Substituting a total of 890 antihypertensive drugs for 774 patients reduced total antihypertensive drug costs by $73.9 \%$, with an average savings of KD 5.68. The 890 drugs substituted corresponded to 22 branded drugs. With an estimated $27.8 \%$ of the population living with elevated blood pressure, we estimate that Kuwait could achieve national cost savings of $\mathrm{KD} 81,328,010.4$ per year for all patients with hypertension, and the sensitivity analysis showed that savings in the case of a lower prevalence of hypertension could still be significant.

Al Kanderi et al. 2009 reported in their study that there was a lack of essential antihypertensive drugs in primary health care clinics in Kuwait. According to the authors, MOH's policy of confining expensive drugs to secondary and tertiary hospitals had likely driven overreliance on these facilities, where the increasing costs of antihypertensive drugs had made them unavailable in primary healthcare centers [43]. Higher costs and drug unavailability can lead to patient noncompliance with therapy and to uncontrolled hypertension, eventually increasing future health care expenditures due to complications [26]. Patients with hypertension often rely on primary health care clinics to regularly check their blood pressure and receive their monthly prescriptions, which is why it could be worthwhile to find a solution to this problem, such as switching to lower-priced generic drugs. Reducing the cost of antihypertensive drugs could increase their availability in primary health care clinics, reducing the pressure on secondaryand tertiary-level hospitals and increasing patient adherence to drug therapies.

Kuwait provides treatment free of charge to its citizens and at a subsidized cost for residents, so the government bears the cost of expensive drug brands. With the aging population and increases in noncommunicable diseases, the price differences between branded and generic drugs should not be 
medRxiv preprint doi: https://doi.org/10.1101/2021.05.07.21256767; this version posted May 14, 2021. The copyright holder for this preprint (which was not certified by peer review) is the author/funder, who has granted medRxiv a license to display the preprint in perpetuity.

It is made available under a CC-BY-NC-ND 4.0 International license .

considered trivial. Even with low-cost medications, cost differences between generic and branded drugs in chronic diseases could translate into thousands of Kuwaiti dinars saved over a given patient's life. Noncommunicable diseases require recurrent and long-term medication services. In particular, cardiovascular

317 diseases and hypertension take up a significant amount of total government health expenditures even as

318 fewer persons might be affected as by other diseases. Cardiovascular diseases require frequent outpatient

319 visits and expensive interventions, they result in intensive care unit admissions, and they are also

320 associated with lengthier hospital stays and work absenteeism [23]. The MOH's reliance on mostly

321 innovator-branded drugs is unnecessary, and the potential savings from increasing the generic penetration

322 in the Kuwaiti market are still untapped [30].

\section{Limitations}

We encountered several challenges in the course of this study. Only three primary care centers were made available to be sampled, and all were from one governorate in Kuwait. Generalizing the current study findings will require a more representative sample from PHCCs across multiple regions of

327 Kuwait. Moreover, we were forced to use the 2015 International Medical Products Price Guide when substituting generic drugs owing to the limited availability of generic drugs in Kuwait.

\section{Conclusion}

Many countries have followed the recommendations of the WHO in promoting the use of generic

331 drugs as a means of bringing down pharmaceutical expenditures and increasing access to medications.

332 Kuwait has recently joined other countries in mandating prescription by generic name and increasing the

333 availability of generics in the Kuwaiti pharmaceutical market, yet the generic prescription rate is still low.

334 With the increasing prevalence of hypertension and its status as a lifelong illness came a necessity for

335 decreasing its cost of treatment. With this study, we aimed to analyze the cost of drugs for managing

336 hypertension in selected primary health care centers in Kuwait and to calculate the amount of savings that

337 could be generated by substituting generic antihypertensive drugs for their branded equivalents. As we

338 expected, only 71 generic drugs had been prescribed, making the generic prescription rate $4.0 \%$, a rate the

339 WHO considers very low. However, even at this low rate, substituting 890 antihypertensive drugs 
medRxiv preprint doi: https://doi.org/10.1101/2021.05.07.21256767; this version posted May 14, 2021. The copyright holder for this preprint (which was not certified by peer review) is the author/funder, who has granted medRxiv a license to display the preprint in perpetuity.

It is made available under a CC-BY-NC-ND 4.0 International license .

reduced total prescription costs by $56.23 \%$ and total antihypertensive drug costs by $73.91 \%$, a promising amount that is in line with reports that prices of generics are anywhere between $10 \%$ and $90 \%$ less than those of originator drugs.

For this study, we estimated the national savings by assuming that all $1,306,600$ patients with hypertension were treated in the same manner at the expense of the government, which carries the risk that we overestimated the savings. However, we did show that even for just one chronic condition, hypertension, the savings generated by substituting generic drugs for their originator brands could be significant enough to warrant policy changes. Barriers persist in Kuwait to the successful implementation of policies that encourage generic prescription, including the absence of national drug policy, the negative perception of the quality of generics, the heavy dependence on imported drugs, and the limited availability of generics in the Kuwaiti pharmaceutical market. These need to be addressed if Kuwait is to achieve a similar generic prescription rate to those reported by most developed countries.

\section{Acknowledgments}

353 Our deepest gratitude for the Primary Healthcare Division of MOH for acquiring the data that made this 354 research possible. Our special thanks is offered to Dr. Donia AlBastaki, Head of the Drug Registration

356 like to thank Enago (www.enago.com) for the English language review.

\section{Author contributions}

358 Concept and design: AO and SA were responsible for conceptualizing and designing the study. AO, SA, 359 RA and $\mathrm{MA}^{2}$ were involved in acquisition of the data. AO \& SA performed the analysis of the data. AO, 360 SA and $\mathrm{MA}^{1}$ carried out the drafting of the manuscript. SA undertook critical revisions of the manuscript

361 for important intellectual content.

\section{Declaring conflict of interest}

363 None declared.

\section{$364 \quad$ Funding}

365 No funding was received. 
medRxiv preprint doi: https://doi.org/10.1101/2021.05.07.21256767; this version posted May 14, 2021. The copyright holder for this preprint (which was not certified by peer review) is the author/funder, who has granted medRxiv a license to display the preprint in perpetuity.

It is made available under a CC-BY-NC-ND 4.0 International license .

\section{References}

367 1. Newman-Casey PA, Woodward MA, Niziol LM, Lee PP, De Lott LB. Brand medications and

368 Medicare Part D: how eye care providers' prescribing patterns influence costs. Ophthalmology. 2018;125: 332-

369339.

370 2. Ali Jadoo SAA, Aljunid SM, Nur AM, Ahmed Z, Van Dort D. Development of MY-DRG casemix

371 pharmacy service weights in UKM Medical Centre in Malaysia. DARU J Pharm Sci. 2015;23: 14.

372 3. Sudhanthar, S., Turner, J., Thakur, K. and Sigal, Y. (2015). Improving viable low cost generic

373 medication prescription rate in primary care pediatric practice. BMJ Quality Improvement Reports, 4(1),

374 pp.u209517.w3931.

375 4. OECD. Health resources - Pharmaceutical spending - OECD Data. 2019. [Cited 2019 Mar 29].

376 Available from: https://data.oecd.org/healthres/pharmaceutical-spending.htm

377 5. OECD. Health at a glance 2011: OECD indicators. Paris: OECD Publishing; 2011.

378 6. Deloitte. Global health care sector outlook. Deloitte. 2019; 2019.. [Cited2019 March 29]. Available

379 from: https://www2.deloitte.com/global/en/pages/life-sciences-and-healthcare/articles/global-health-care-

380 sector-outlook.html

381 7. William 44. Russell W. What is driving up the cost of global healthcare? | William Russell. 2017.

382 [Cited 2019 March 29]. Available from: https://www.william-russell.com/blogs/driving-cost-global-

383 healthcare/.

3848 . Investopedia. Why do healthcare costs keep rising? 2018. Available from:

385 https://www.investopedia.com/insurance/why-do-healthcare-costs-keep-rising.

$3869 . \quad$ Docteur E, Paris V. Ensuring efficiency in pharmaceutical expenditures. In: OECD, achieving better

387 value for money in health care. OECD Publishing; 2009.

388 10. Mathew P. Generic drugs: review and experiences from South India. J Fam Med Prim Care. 2015;4:

$389 \quad 319-323$.

390 11. Liberman JN, Roebuck MC. Prescription drug costs and the generic dispensing ratio. J Manag Care

391 Pharm. 2010;16: 502-506. 
medRxiv preprint doi: https://doi.org/10.1101/2021.05.07.21256767; this version posted May 14, 2021. The copyright holder for this preprint (which was not certified by peer review) is the author/funder, who has granted medRxiv a license to display the preprint in perpetuity.

It is made available under a CC-BY-NC-ND 4.0 International license .

12. Hassali MA, Alrasheedy AA, McLachlan A, Nguyen TA, AL-Tamimi SK, Ibrahim MI, et al. The experiences of implementing generic medicine policy in eight countries: a review and recommendations for a successful promotion of generic medicine use. Saudi Pharm J. 2014;22: 491-503.

395 13. Association for Accessible Medicines. Generic drug access \& savings in the U.S. Washington:

396 Accessible Medicines. 2018 [Cited 2019 April 22]. Available from:

397 https://accessiblemeds.org/sites/default/files/2018_aam_generic_drug_access_and_savings_report.pdf

398 14. The King's Fund. How much has generic prescribing and dispensing saved the NHS? 2019. [Cited 2019 April 22]. Available from: https://www.kingsfund.org.uk/blog/2015/07/how-much-has-generic-

400 prescribing-and-dispensing-saved-nhs.

401 15. Prices of Canadian generic medicines Below international average - Canadian generic pharmaceutical 402 association. Canadiangenerics.ca. 2020). [Cited 2020 Sep4], Available from: https://canadiangenerics.ca/news403 release622/prices-of-canadian-generic-medicines-below-international-average/.

404 16. Awad A, Al-Saffar N. Evaluation of drug use practices at primary healthcare centers of Kuwait. Eur J 405 Clin Pharmacol. 2010;66: 1247-1255.

406 17. Ofori-Asenso R. A closer look at the World Health Organization's prescribing indicators. J Pharmacol 407 Pharmacother. 2016;7: 51-54.

408 18. Gaziano TA, Bitton A, Anand S, Weinstein MC, International Society of Hypertension. The global 409 cost of nonoptimal blood pressure. J Hypertens. 2009;27: 1472-1477.

410 19. Kuwait. Institute for Health Metrics and Evaluation. (2020). Retrieved 14 June 2020, from 411 http://www.healthdata.org/kuwait.

412 20. Drugs.com. Prescription Drug Information, Interactions \& Side Effects. Available from:

413 https://www.drugs.com/; 2021.

414 21. Defined daily dose (DDD). Available from: https://www.who.int/medicines/regulation/medicines-

415 safety/toolkit_ddd/en/. World Health Organization; 2020.

416 22. International medical products price guide. 2015. Available from: http://mshpriceguide.org/wp417 content/uploads/2017/04/MSH-2015-International-Medical-Products-Price-Guide.pdf. 
medRxiv preprint doi: https://doi.org/10.1101/2021.05.07.21256767; this version posted May 14, 2021. The copyright holder for this preprint (which was not certified by peer review) is the author/funder, who has granted medRxiv a license to display the preprint in perpetuity.

It is made available under a CC-BY-NC-ND 4.0 International license .

23. El-Reshaid K, Al-Owaish R, Diab A. Hypertension in Kuwait: the past, present and future. Saudi J

Kidney Dis Transpl. 1999; 10: 357-364. [Cited 2020 Sep 3]. Available from:

http://www.sjkdt.org/text.asp?1999/10/3/357/37244.

421 24. Fryar CD, Ostchega Y, Hales CM, Zhang G, Kruszon-Moran D. Hypertension prevalence and control

422 among adults: United States, 2015-2016. NCHS Data Brief. Hyattsville, MD: National Center for Health

423 Statistics. 2017. Available from: https://www.cdc.gov/nchs/data/databriefs/db289.pdf;289: 1-8.

424 25. Al-Jahrā'(Governorate, Kuwait) - Population Statistics, Charts, Map and Location. (2020)

425 Citypopulation.de. [Cited 2020 June 15]. Available from:

426 https://www.citypopulation.de/en/kuwait/admin/4_al_jahr\%C4\%81/.

427 26. Al-Mehza AM, Al-Muhailije FA, Khalfan MM, Al-Yahya AA.Drug Compliance Among

428 Hypertensive Patients; an Area Based Study. Electron J Gen Med. 2009;6: 6-10.

429 27. Ministry of Health. MOH obliges doctors with generic prescribing. Kuwait: Health Media Office;

4302020.

431 28. Abdulsalam Y. The role of doctors in Kuwait's healthcare costs. LSE Middle East Centre Paper

432 Series. 29. London, UK: LSE Middle East Centre; 2019.

433 29. Sarpatwari A, Choudhry NK, Avorn J, Kesselheim AS. Paying physicians to prescribe generic drugs

434 and follow-on biologics in the United States. PLOS Med. 2015;12: e1001802.

435 30. Ball D, Tisocki K, et al. Saffar, N. Medicine Prices, availability, affordability and price components,

436 Kuwait. 2009. Available from: http://haiweb.org/wp-content/uploads/2015/07/Kuwait-summary-report-

437 pricing-surveys.pdf.

438 31. Ken Research Private Limited. Kuwait Pharmaceuticals Market Outlook to;2022 - . By type of drugs; 439 by channel of distribution and by therapeutic class. 2018. Available from:

440 https://www.researchandmarkets.com/reports/4769096/kuwait-pharmaceuticals-market-outlook-to-2022\#pos-

4410.

442 32. Al-Junid SM, Ezat WP, Surianti S. Prescribing patterns and drug cost among cardiovascular patients

443 in Hospital Universiti Kebangsaan Malaysia. Med J Malaysia. 2007;62: 59-65. 
medRxiv preprint doi: https://doi.org/10.1101/2021.05.07.21256767; this version posted May 14, 2021. The copyright holder for this preprint (which was not certified by peer review) is the author/funder, who has granted medRxiv a license to display the preprint in perpetuity.

It is made available under a CC-BY-NC-ND 4.0 International license .

$444 \quad 33 . \quad$ Jeragh-Alhaddad FB, Waheedi M, Barber ND, Brock TP. Barriers to medication taking among

445 Kuwaiti patients with type 2 diabetes: a qualitative study. Patient Preference Adherence. 2015;9: 1491-1503.

$446 \quad 34 . \quad$ Arab Times. Kuwait approves purchase and sale of drugs. 2019 [Cited 2020 March 17]. Available

447 from: https://www.arabtimesonline.com/news/kuwait-approves-purchase-and-sale-of-generic-drugs/.

448 35. Kuwait News Agency. Kuwait MOH oks generic drugs. 2019. [Retrieved 17 March 2020] Available

449 from: https://www.kuna.net.kw/ArticleDetails.aspx?id=2824501\&Language=enKuwait.

450 36. Bramlage P, Böhm M, Volpe M, Khan BV, Paar WD, Tebbe U, et al. A global perspective on blood

451 pressure treatment and control in a referred cohort of hypertensive patients. J Clin Hypertens (Greenwich).

$452 \quad 2010 ; 12: 666-677$

453 37. Al Duraihim H, Alghamdi G, AlNemer M, Abdulaal AE, Al Sayyari A. Blood pressure control,

454 lifestyle and disease awareness of Saudi hypertensive patients. Saudi J Kidney Dis Transpl. 2019;30: 33-38.

455 38. Jassim Al Khaja KA, Sequeira RP, Wahab AW, Mathur VS. Antihypertensive drug prescription trends

456 at the primary health care centres in Bahrain. Pharmacoepidemiol Drug Saf. 2001;10: 219-227.

457 39. AlDrabah E, Irshaid Y, Yasein N, Zmeili S. Prescription pattern of antihypertensive drugs in Family

458 Practice Clinics at Jordan University Hospital. Med Sci Int Med J. 2013;2: 469.

459 40. Gu Q, Burt VL, Dillon CF, Yoon S. Trends in antihypertensive medication use and blood pressure

460 control among United States adults with hypertension: the National Health And Nutrition Examination Survey,

4612001 to 2010. Circulation. 2012 Oct 23;126(17):2105-14. doi: 10.1161/CIRCULATIONAHA.112.096156.

462 PMID: 23091084.

463 41. Moser, M. (1998). The cost of treating hypertension can we keep it under control without

464 compromising the level of care?. American Journal Of Hypertension, 11(3), 120S-127S.

465 https://doi.org/10.1016/s0895-7061(98)00106-x

466 42. Cameron A, Mantel-Teeuwisse AK, Leufkens HG, Laing RO. Switching from originator brand

467 medicines to generic equivalents in selected developing countries: how much could be saved? Value Health.

$468 \quad 2012 ; 15: 664-673$.

469 43. AL-Kanderi BM, AL-Otaibi M, AL-Abdulghani K.Limited Availability of Anti-Hypertensive

470 Medications in Primary Care in Kuwait. Electron J Gen Med. 2009;6. 
475 Appendix

476 Table 11: Substituted hypertension drugs

Brand Name of drug

Generic (scientific) name of drug 478

Adalat LA 30

Nefidipine

479

Aldactone $25 \& 100$

Spironolactone

480

Aldomet $250 \& 500$

Methyldopa

481

Capoten $25 \& 50$

Captopril

482

Concor 5

Bisoprolol

483

Esidrex

Hydrochlorothiazide

484

Inderal $10 \& 40$

Propranolol

485

Isoptin 80 \& SR 240

Verapamil

486

Istin 10

Amlodipine

487

Lasix

Furosemide

488

Lopresor 100

Metoprolol

489

Norvasc

Amlodipine

490

Tenol $50 \& 100$

Atenolol

491

Tenolol 50

Atenolol

492

Tenormin $50 \& 100$

Atenolol

Zestoretic

Lisinopril/Hydrochlorothiazide

494

Zestril 5, 10, 15 and 20

Lisinopril

495

Cozaar 50

Losartan

496 
501

502 Table 12: Unsubstituted hypertension drugs.

Brand Name of drug

Atacand 8 \&16

Co-diovan 80/12.5 \& 160/12.5

Concor $2.5 \& 10$

Coversyl $4 \& 5 \& 10$

Diovan $80 \& 160$

Exforge 10/160

Exforge HCT 10/160/12.5

Lercadip 10

Lopresor 50

Micardis $40 \& 80$

Micardis plus 40/12.5

Minipress 2

Moduretic

Natrilix SR 1.5

Physiotens $0.2 \& 0.4$

Tenoretic

Triplixam

Inhibace

Atelec
Generic (scientific) name of drug

Candesartan

Valsartan/Hydrochlorothiazide

Bisoprolol

Perindopril

Valsartan

Amlodipine/Valsartan

Amlodipine/Valsartan/Hydrochlorothiazide

Lercadipine

Metoprolol

Telmisartan

Telmisartan/Hydrochlorothiazide

Prazosin

Amiloride $\mathrm{HCl} / \mathrm{Hydrochlorothiazide}$

Indapamide

Moxonidine

Atenolol/Chlorthalidone

Perindopril/Indapamide/amlodipine

Cilazapril

Cilndipine 